\title{
Effects of iron loading on muscle: genome-wide mRNA expression profiling in the mouse
}

\author{
Alejandra Rodriguez ${ }^{* 1}$, Mika Hilvo ${ }^{1}$, Leena Kytömäki², Robert E Fleming ${ }^{3,4}$, \\ Robert S Britton ${ }^{5}$, Bruce R Bacon ${ }^{5}$ and Seppo Parkkila ${ }^{1,6}$
}

Address: ${ }^{1}$ Institute of Medical Technology, University of Tampere and Tampere University Hospital, Tampere, Finland, ${ }^{2}$ Turku Centre for Biotechnology, University of Turku, Turku, Finland, ${ }^{3}$ Department of Pediatrics, Saint Louis University School of Medicine, St. Louis, USA, ${ }^{4}$ Edward A. Doisy Department of Biochemistry and Molecular Biology, Saint Louis University School of Medicine, St. Louis, USA, ${ }^{5}$ Department of Internal Medicine, Saint Louis University School of Medicine, St. Louis, USA and ${ }^{6}$ Department of Clinical Chemistry, University of Oulu, Oulu, Finland

Email: Alejandra Rodriguez* - alejandra.rodriguez.martinez@uta.fi; Mika Hilvo - mika.hilvo@uta.fi; Leena Kytömäki - leena.kytomaki@btk.fi; Robert E Fleming - flemingr@slu.edu; Robert S Britton - brittonr@slu.edu; Bruce R Bacon - baconbr@slu.edu;

Seppo Parkkila - seppo.parkkila@uta.fi

* Corresponding author

Published: 19 October 2007

BMC Genomics 2007, 8:379 doi:I0.1/86/|47|-2164-8-379
Received: 2I May 2007

Accepted: 19 October 2007

This article is available from: http://www.biomedcentral.com/I47I-2I64/8/379

(c) 2007 Rodriguez et al; licensee BioMed Central Ltd.

This is an Open Access article distributed under the terms of the Creative Commons Attribution License (http://creativecommons.org/licenses/by/2.0), which permits unrestricted use, distribution, and reproduction in any medium, provided the original work is properly cited.

\begin{abstract}
Background: Hereditary hemochromatosis $(\mathrm{HH})$ encompasses genetic disorders of iron overload characterized by deficient expression or function of the iron-regulatory hormone hepcidin. Mutations in 5 genes have been linked to this disease: HFE, TFR2 (encoding transferrin receptor 2), HAMP (encoding hepcidin), SLC4OAI (encoding ferroportin) and HJV (encoding hemojuvelin). Hepcidin inhibits iron export from cells into plasma. Hemojuvelin, an upstream regulator of hepcidin expression, is expressed in mice mainly in the heart and skeletal muscle. It has been suggested that soluble hemojuvelin shed by the muscle might reach the liver to influence hepcidin expression. Heart muscle is one of the target tissues affected by iron overload, with resultant cardiomyopathy in some $\mathrm{HH}$ patients. Therefore, we investigated the effect of iron overload on gene expression in skeletal muscle and heart using Illumina ${ }^{\mathrm{TM}}$ arrays containing over 47,000 probes. The most apparent changes in gene expression were confirmed using real-time RT-PCR.

Results: Genes with up-regulated expression after iron overload in both skeletal and heart muscle included angiopoietin-like 4, pyruvate dehydrogenase kinase 4 and calgranulin $\mathrm{A}$ and $\mathrm{B}$. The expression of transferrin receptor, heat shock protein IB and Dnal homolog BI were downregulated by iron in both muscle types. Two potential hepcidin regulatory genes, hemojuvelin and neogenin, showed no clear change in expression after iron overload.

Conclusion: Microarray analysis revealed iron-induced changes in the expression of several genes involved in the regulation of glucose and lipid metabolism, transcription and cellular stress responses. These may represent novel connections between iron overload and pathological manifestations of $\mathrm{HH}$ such as cardiomyopathy and diabetes.
\end{abstract}




\section{Background}

It is crucial for the human body to maintain iron homeostasis. Since there is no adjustable mechanism to influence iron loss from the body, tight regulation of iron absorption at the intestinal level is vital [1]. In order to maintain iron balance, iron export from enterocytes, reticuloendothelial macrophages and hepatocytes into the blood stream has to be controlled as well. Functional derangement of proteins involved in these regulatory mechanisms can cause hereditary hemochromatosis (HH, OMIM235200). This genetic disorder of iron overload is characterized by high transferrin saturation, low iron content in macrophages, and deposition of iron in several organs including the liver, heart, and pancreas. Causative mutations for $\mathrm{HH}$ have been described in several genes, namely HFE, TFR2 (encoding transferrin receptor 2), HJV (encoding hemojuvelin), and HAMP (encoding hepcidin) [2-7]. It has been proposed that these mutations cause deficient hepcidin synthesis $[4,5,8,9]$.

The antimicrobial peptide hepcidin is the central regulator of iron metabolism. It is produced mainly in the liver and exerts its function by binding to the iron export protein, ferroportin, inducing its internalization and degradation [10]. Ferroportin is located in the cellular membranes of enterocytes, reticuloendothelial cells, hepatocytes and placental cells [11]. Therefore, hepcidin acts to decrease the export of iron from these cells into the circulation.

Hemojuvelin is a glycosyl phosphatidylinositol-anchored protein which belongs to the repulsive guidance molecule (RGM) protein family $[4,12]$. Recent studies suggest that hemojuvelin exists in two forms. One is a rarer full-length protein shed to the extracellular fluid, where it has a long half-life. The other is a smaller, membrane-associated disulfide-linked heterodimer, which is a more abundant but shorter-lived form composed of $\mathrm{N}$ - and C-terminal fragments $[13,14]$. According to latest studies the most common mutation in hemojuvelin (G320V) affects the targeting of the membrane-associated form and reduces the amount of the soluble form [15]. Interestingly, studies in cultured cells suggest that the two forms regulate hepcidin expression reciprocally by competing for a receptor binding site [14]. Evidence shows that hemojuvelin is a bone morphogenetic protein co-receptor, and its interaction with BMP initiates a signaling cascade that leads to regulation of hepcidin expression $[16,17]$. On the other hand, it has been observed that overexpressed hemojuvelin binds to the membrane receptor neogenin and that this interaction is required for the accumulation of iron in cultured cells [12]. Zhang et al. also showed that the G320V mutated hemojuvelin overexpressed in vitro was not able to bind neogenin, and that iron did not accumulate in the cells under these conditions. Furthermore, a recent study in cultured cells suggested that neogenin may mediate inhibition of hemojuvelin shedding in response to iron [18]. We have previously determined the sites of simultaneous expression of hemojuvelin and neogenin [19]. The highest expression of hemojuvelin transcript is found in the skeletal muscle and heart. Although in vivo evidence of a combined role of hemojuvelin and neogenin in iron homeostasis has not been provided yet, it has been suggested that hemojuvelin shed from skeletal muscle and heart by neogenin-dependent mechanism could reach the liver to influence hepcidin expression [12].

Cardiomyopathy develops in some HH patients [20]. In order to better understand the mechanisms behind pathological effects of iron overload in muscle cells, we have performed a genome-wide expression analysis of genes in skeletal muscle and heart of mice with or without dietary iron loading. Microarray data analysis identified several genes whose expression was either down- or up-regulated due to iron overload. These results may reveal novel links between iron overload and pathological manifestations of $\mathrm{HH}$.

\section{Results \\ Documentation of iron overload in the liver and heart of iron-fed mice}

The mice were fed either standard ( $0.02 \%$ carbonyl iron) or high-iron ( $2 \%$ carbonyl iron) diet for 6 weeks. Iron concentrations of liver and heart specimens were determined to confirm the validity of the animal model. Figure 1A demonstrates that the livers of mice of all three strains were highly iron-loaded when fed an iron-rich diet. A much smaller increment in cardiac iron content after a high-iron diet was observed also in all three strains and in both genders (Figure 1B), although statistical significance was not reached in all the cases. Basal cardiac iron levels were lower than basal hepatic contents. In general, female mice showed slightly higher hepatic and cardiac iron levels than male mice.

\section{Identification and validation of changes in gene expression induced by dietary iron overload in skeletal muscle and heart}

We obtained a list of 14 genes with iron-induced up-regulated expression in skeletal muscle (Table 1) and forty with down-regulated expression (Table 2). In the heart, iron loading resulted in the up-regulation of 35 genes (Table 3), while forty genes had down-regulated expression after iron overload (Table 4). There were seven genes which were up-regulated in both the heart and skeletal muscle, while nine genes were down-regulated in both tissues.

From the lists of microarray results we selected 15 genes which presented the highest fold change values. The 

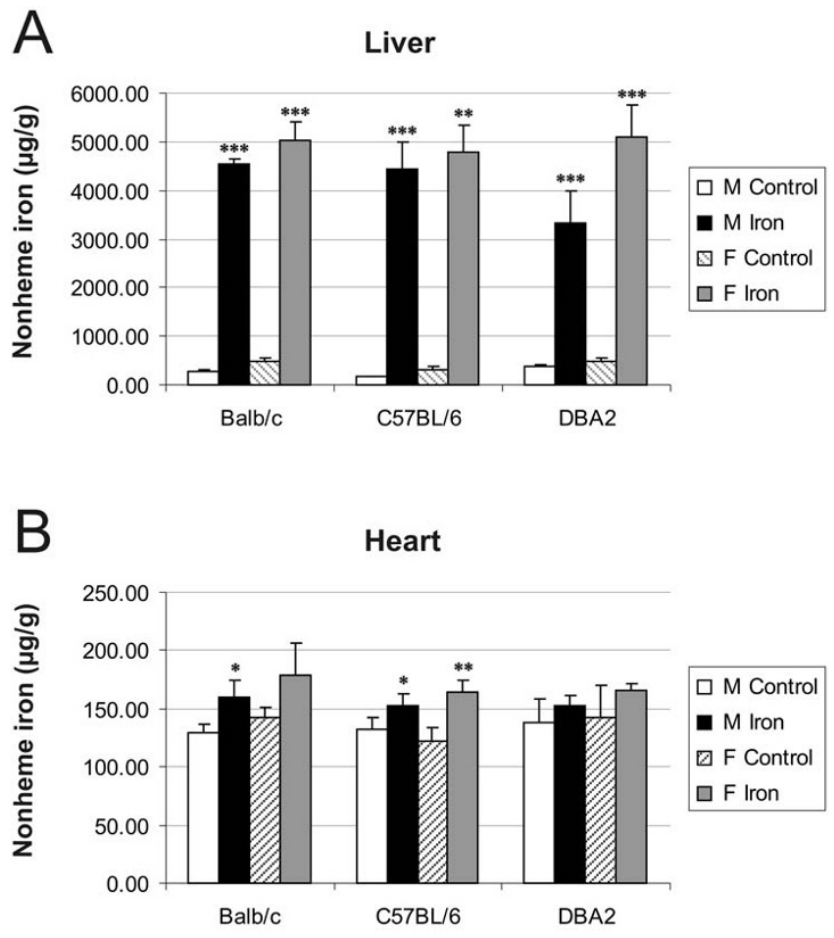

\section{Figure I}

Hepatic and cardiac non-heme iron concentrations. Iron contents were studied in three strains of male and female mice fed either the control or high-iron diet. The result values are expressed as mean $+/$ - standard deviation. Statistical significant differences relative to control diet fed mice were determined. ${ }^{*} p<0,05 ;{ }^{*} p<<0,0$ I; ***p $<0,00 \mathrm{I}$. F = female; $M=$ male.

expression levels of these genes were then analyzed in the same mouse strain (C57BL/6) by Q-RT-PCR (quantitative reverse-transcription PCR). Certainly, the results from these analyses showed a good correlation between the two methods; the expression of all the genes was regulated and displayed the same direction of change. The fold change values obtained from PCR experiments were all over 1.4 except for the Tfrc gene whose downregulation in the skeletal muscle reached the value of -1.36 .

Representations of these Q-RT-PCR results are depicted in figures 2 and 3. In general, the fold-change values obtained by microarray analysis were smaller than those determined by Q-RT-PCR. This phenomenon has been described previously and is probably due to the fact that array analyses are less quantitative than Q-PCR [21].

The hepatic mRNA levels of these 15 genes were also analyzed by Q-RT-PCR. The results for genes whose expression varied in the same direction in both skeletal muscle and heart after iron loading are shown together with their expression in the liver in Figure 4. The expression of four of the 15 genes (Myl4, Myl7, Acta1 and Adn) was considered negligible in the liver because of very low signal intensity. Among the 11 remaining genes only the hepatic expression of Pdk4 (shown in figure 4B) and Cxcl7 (fold change of +1.38 , data not shown) was not significantly regulated by dietary iron.

\section{Expression of genes involved in hepcidin regulatory pathway during dietary iron overload}

One of the aims of this study was to explore the effect of dietary iron overload on the expression of the iron-related genes hemojuvelin $(\mathrm{Hjv})$ and neogenin $(\mathrm{Neo})$ in skeletal muscle and heart. We did not observe differential expression of these genes or any of the traditional iron-regulatory genes (such as Cybrd1, Slc11a2, Slc40a1, Heph, Trfr2, Hfe or Hamp) by the microarray approach, except for the transferrin receptor gene (Tfrc), which was down-regulated by iron in heart, skeletal muscle and liver (Figure $4 \mathrm{E})$. Even though the microarray method we used proved to be very accurate, we wanted to verify these results and to explore the response of hepcidin expression in the studied tissues by Q-RT-PCR.

The expression of hepcidin 1 and hepcidin 2 in the liver was greatly up-regulated by iron overload and varied according to mouse strain and gender $[22,23]$. In Balb/c and $\mathrm{C} 57 \mathrm{BL} / 6$ mice, hepcidin 1 was the predominant form expressed in the liver, while in DBA2 mice, the hepatic expression of hepcidin 2 was dominant (Figures 5C and Figure 6C). The expression of hepcidin 1 in the skeletal muscle was negligible in all strains (Figure 5A). In the heart muscle, it showed a slight tendency towards decreased expression in most iron fed mice, although the baseline signal in control mice was already quite low (Figure 5B). Only DBA2 mice expressed hepcidin2 in the skeletal muscle and heart, and this expression was not clearly regulated by iron overload (Figure 6A and 6B).

The results for hemojuvelin expression did not indicate any clear regulation by iron overload, strain or gender in any of the tissues studied (Figure 7). This is in agreement with previous studies of hepatic expression $[24,25]$. Hemojuvelin expression only showed a minor trend downwards in skeletal muscle and heart of mice fed with high-iron diet. No significant changes were observed for neogenin expression (Figure 8).

\section{Discussion}

Excess free iron participates in the formation of free radicals causing oxidative stress and cell damage, which is evidenced as a series of pathological manifestations [26]. While some studies have analyzed the effects of iron on the transcriptional profiles in liver and duodenum, this is the first study reporting changes in mRNA expression that may contribute to iron-induced effects on skeletal muscle 
Table I: Genes with up-regulated expression in skeletal muscle during iron overload

\begin{tabular}{|c|c|c|c|}
\hline Gene name & Symbol & Accession. & Fold change \\
\hline Calgranulin A, SI00 calcium binding protein A8 & S100a8 & NM 013650 & 2.80 \\
\hline Calgranulin B, SI00 calcium binding protein A9 & S100a9 & NM 009114 & 2.26 \\
\hline Stearoyl-Coenzyme A desaturase I & Scdl & NM 009127 & 1.75 \\
\hline Adipsin, complement factor D & Adn & NM 013459 & 1.62 \\
\hline Myosin light polypeptide 2 & Myl2 & NM 010861 & 1.60 \\
\hline UDP-N-acetyl-alpha-D-galactosamine:polypeptide $\mathrm{N}$-acetylgalactosaminyl transferase-like 2 & Galntl2 & $\underline{X M \quad 127638}$ & 1.56 \\
\hline cytochrome P450, family 26 , subfamily b, polypeptide I & Cyp26bl & NM 175475 & 1.49 \\
\hline cold inducible RNA binding protein & Cirbp & NM 007705 & 1.48 \\
\hline Cbp/p300-interacting transactivator, with Glu/Asp-rich carboxy-terminal domain, 2 & Cited2 & NM 010828 & 1.46 \\
\hline angiopoietin-like 4 & Angptl4 & NM 02058I & 1.45 \\
\hline epididymal protein Av381 I26 & & NM 183143 & 1.45 \\
\hline pyruvate dehydrogenase kinase, isoenzyme 4 & Pdk4 & NM 013743 & 1.40 \\
\hline myeloid/lymphoid or mixed lineage-leukemia translocation to 4 homolog (Drosophila) & Mllt4 & XM 890447 & 1.40 \\
\hline 6-phosphofructo-2-kinase/fructose-2,6-biphosphatase 3 & Pfkfb3 & NM 133232 & 1.40 \\
\hline
\end{tabular}

Data obtained with 3 high-iron and 3 control samples.

and heart. We used a genome-wide mRNA expression profiling approach and validated the most substantive changes by Q-RT-PCR.

Expression of antioxidant enzymes is considered a protective mechanism against oxidative stress-induced damage. However, the regulation of antioxidant enzymes in response to oxidative stress is a rather controversial issue, as the results vary greatly depending on the type and length of the stimulus and the type of cells or tissue tested. We did not find increased expression of oxidative stressrelated genes or antioxidant enzymes after iron overload, except for glutathione peroxidase 3 , whose expression was induced by 1.35 -fold change in heart (data not shown).

The data analysis identified two genes encoding calciumand zinc-binding proteins, S100a8 (calgranulin A) and S100a9 (calgranulin B) among the up-regulated genes presenting the highest fold changes. These proteins form a rather ubiquitous heterodimer called calprotectin. The highest amounts of this protein complex are located in neutrophil granulocytes, monocytes and keratinocytes [27]. Calprotectin is a pro-inflammatory cytokine that is upregulated in many inflammatory conditions, and is involved in innate immunity, leukocyte adhesion, endothelial transmigration and processes of chronic inflammation [28]. In vitro studies have shown that reactive oxygen species (ROS) induce protein levels of S100a9 [29]. Additionally, S100a8 expression is induced in keratinocytes upon exposure to ultraviolet A (UVA) radiation, a stimulus causing oxidative stress. Interestingly, the antioxidant enzymes superoxide dismutase and catalase, whose mRNA expression was unaffected in our microarray, abrogate S100a8 induction [30]. We found that both S100a8 and S100a9 transcripts were substantially up-regulated in skeletal muscle, heart and liver of iron-loaded mice, although the levels of S100a8 transcript in skeletal muscle were negligible and, in general, both genes were weakly expressed. This demonstrates the high sensitivity and accuracy of both the microarray analysis and the QRT-PCR method. It is noteworthy that S100a8 and S100a9 transcripts showed a very similar up-regulation pattern in the tissues studied, which agrees with the concept of the two proteins forming a heterodimer. The transcriptional regulation of the S100a8 and S100a9 genes seems to be rather complex, with promoter binding sites for transcription factors such as activator protein 1 (AP-1), nuclear factor kappa B (NF- $\mathrm{BB}$ ) and C/EBP. Consistently, at least AP1 and NF- $\kappa B$ have been previously identified to be regulated by the intracellular redox state [31].

Pyruvate dehydrogenase kinase 4 (Pdk4) phosphorylates and inactivates the pyruvate dehydrogenase complex, decreasing the rate of glucose oxidation and thus increasing blood glucose levels. Increased Pdk4 expression and activity has been observed in both skeletal muscle $[32,33]$ and heart [34] of insulin-resistant mouse models. The question arises of whether Pdk4 overexpression causes insulin resistance or vice versa. Insulin suppresses Pdk4 expression in skeletal muscle [35] and, according to a recent study by Kim and coworkers [36], this effect is impaired in insulin resistance, suggesting that insulin resistance may indeed induce Pdk4 expression. However, several studies using high-fat dietary models of insulin resistance indicate that Pdk4 overexpression occurs before the development of insulin resistance [37-39]. Although it has not been documented directly that increased Pdk4 mRNA levels can indeed cause insulin resistance, it seems possible that a vicious cycle may exist between these two phenomena. In the present study, we show an up-regulation of Pdk4 mRNA levels in skeletal muscle and heart but not in the liver of iron-loaded mice. Diabetes mellitus is 
Table 2: Genes with down-regulated expression in skeletal muscle during iron overload

\begin{tabular}{|c|c|c|c|}
\hline Gene name & Symbol & Accession. & Fold change \\
\hline major urinary protein I & Mupl & NM 031188 & -2.61 \\
\hline Dnaj (Hsp40) homolog, subfamily B, member I & Dnajbl & NM 018808 & -2.52 \\
\hline Heat shock protein IB & Hspalb & NM 010478 & -2.40 \\
\hline solute carrier family 25 (mitochondrial carrier, phosphate carrier), member 25 & Slc25a25 & NM 146118 & -2.22 \\
\hline major urinary protein 3 & Mup3 & NM 010845 & -2.21 \\
\hline FBJ osteosarcoma oncogene & Fos & NM 010234 & -2.10 \\
\hline heat shock protein I, alpha & Hspca & NM 010480 & -1.91 \\
\hline early growth response 3 & Egr3 & NM 018781 & -1.79 \\
\hline metallothionein I & $\mathrm{Mtl}$ & NM 013602 & -1.78 \\
\hline heat shock protein 105 & Hspl05 & NM 013559 & -1.72 \\
\hline $\begin{array}{l}\text { RIKEN full-length enriched library, clone:A530098C I I product: hypothetical SAM (and some other } \\
\text { nucleotide) binding motif containing protein }\end{array}$ & & $\underline{A K 041301}$ & -1.70 \\
\hline ERBB receptor feedback inhibitor I & Errfil & NM 133753 & -1.69 \\
\hline inhibitor of DNA binding I & $|d b|$ & NM 010495 & -1.66 \\
\hline Transthyretin & $\operatorname{Ttr}$ & NM 013697 & -1.65 \\
\hline Kruppel-like factor 4 & KIf4 & NM 010637 & -1.65 \\
\hline nuclear factor, interleukin 3 , regulated & Nfil3 & NM 017373 & -1.64 \\
\hline cyclin-dependent kinase inhibitor IA & Cdknla & NM 007669 & -1.62 \\
\hline $\begin{array}{l}\text { RIKEN full-length enriched library, clone:D830037I2I product:weakly similar to RING ZINC FINGER } \\
\text { PROTEIN SMRZ [Homo sapiens] }\end{array}$ & & AK052911 & -1.61 \\
\hline protein phosphatase I, regulatory subunit 10 & PpplrI0 & NM 175934 & -1.61 \\
\hline connective tissue growth factor & Ctgf & NM 010217 & -1.59 \\
\hline serine (or cysteine) proteinase inhibitor, clade $\mathrm{H}$, member I & Serpinhl & NM 009825 & -1.58 \\
\hline cerebellar degeneration-related 2 & Cdr2 & NM 007672 & -1.58 \\
\hline neural precursor cell expressed, developmentally down-regulated gene 9 & Nedd9 & NM 017464 & -1.58 \\
\hline apolipoprotein A-II & Apoa2 & NM 013474 & -1.54 \\
\hline DNA-damage-inducible transcript 4 & Ddit4 & NM 029083 & -1.54 \\
\hline PDZ and LIM domain I & Pdlim I & NM 016861 & -1.51 \\
\hline activating transcription factor 3 & Atf3 & NM 007498 & -1.49 \\
\hline heat shock protein IA & Hspala & NM 010479 & -1.48 \\
\hline heat shock protein I & Hspbl & NM 013560 & -1.48 \\
\hline neural precursor cell expressed, developmentally down-regulated gene 9 & Nedd9 & NM 017464 & -1.47 \\
\hline actin, alpha, cardiac & Actcl & NM_009608 & -1.46 \\
\hline inositol hexaphosphate kinase 3 & Ihpk3 & NM 173027 & -1.45 \\
\hline kidney androgen regulated protein & Kap & NM 010594 & -1.44 \\
\hline metallothionein 2 & Mt2 & NM 008630 & -1.44 \\
\hline 8430408G22Rik & & NM 145980 & -1.43 \\
\hline cyclin-dependent kinase inhibitor IA & Cdknla & NM 007669 & -1.42 \\
\hline G0/GI switch gene 2 & G0s2 & NM 008059 & -1.42 \\
\hline fos-like antigen 2 & Fosl2 & NM 008037 & -1.42 \\
\hline procollagen, type I, alpha I & Collal & NM 007742 & $-1.4 \mid$ \\
\hline dysferlin interacting protein I & Dysfipl & NM 026814 & -1.40 \\
\hline
\end{tabular}

Data obtained with 3 high-iron and 3 control samples.

the major endocrine disorder associated with $\mathrm{HH}$. The mechanisms responsible for this clinical manifestation are still obscure, but two processes have been proposed: the pancreatic $\beta$-cell iron accumulation results in cell damage and diminished insulin secretion, and liver iron overload leads to insulin resistance [40]. The herein reported induction of Pdk4 expression in the skeletal and heart muscle might represent a novel mechanism involved in the development of diabetes mellitus in $\mathrm{HH}$.

Angiopoietin-like 4 (Angptl4) is a secreted protein produced mainly in fat tissue, and to a lesser extent in liver, placenta, skeletal muscle and heart. It is directly involved in regulating glucose homeostasis, lipid metabolism, and insulin sensitivity. Angptl4 decreases the activity of lipoprotein lipase (LPL), thus inhibiting lipoprotein metabolism and increasing plasma triglyceride levels. Transgenic mice with Angptl4 overexpression directed to heart muscle (lipoprotein-derived fatty acids are the major energy source in this tissue) show reduced cardiac LPL activity, decreased triglyceride utilization and impaired cardiac function resulting in cardiomyopathy [41]. Transgenic overexpression of Angptl4 from a liver-specific promoter causes hypertriglyceridemia similar to that induced by 
adenoviral over-expression [42]. These results support the hypothesis that Angptl4 has LPL-dependent actions [43]. Accordingly, in LPL-expressing tissues (muscle, heart and cle and heart of iron-loaded mice might have its origin in a common mechanism. The forkhead transcription factor Foxo1 is a major regulator of insulin action in insulin-sen-

Table 3: Genes with up-regulated expression in the heart during iron overload

\begin{tabular}{|c|c|c|c|}
\hline Gene name & Symbol & Accession. & Fold change \\
\hline myosin, light polypeptide 7 , regulatory & Myl7 & NM 022879 & $7.68 * *$ \\
\hline myosin, light polypeptide 4 , alkali & Myl4 & NM_010858 & $6.32 * *$ \\
\hline seminal vesicle secretion 5 & Svs5 & $\overline{N M 009301}$ & $5.21 * *$ \\
\hline seminal vesicle protein 2 & Svp2 & NM 009300 & $4.25 * *$ \\
\hline myosin binding protein $\mathrm{H}$-like & Mybphl & NM 02683I & 4.14 ** \\
\hline angiopoietin-like 4 & Angptl4 & NM 02058I & $2.79 *$ \\
\hline seminal vesicle protein, secretion 2 & Svs2 & NM 017390 & $2.61 * *$ \\
\hline pyruvate dehydrogenase kinase, isoenzyme 4 & Pdk4 & NM 013743 & $2.06 *$ \\
\hline SI00 calcium binding protein $A 8$ (calgranulin $A)$ & $\mathrm{S} 100 \mathrm{a} 8$ & NM 013650 & $1.96 *$ \\
\hline S100 calcium binding protein A9 (calgranulin B) & S100a9 & $\overline{N M 009114}$ & $1.95 *$ \\
\hline 3-hydroxy-3-methylglutaryl-Coenzyme A synthase 2 & Hmgcs2 & NM 008256 & $1.82 * *$ \\
\hline Ras-related associated with diabetes & Rrad & NM 019662 & $1.81 * *$ \\
\hline thioredoxin interacting protein & Txnip & NM 023719 & $1.78 *$ \\
\hline secretory leukocyte protease inhibitor & Slpi & NM 011414 & $1.69 * *$ \\
\hline dickkopf homolog 3 (Xenopus laevis) & Dkk3 & NM 015814 & $1.68 * *$ \\
\hline START domain containing 10 & Stard IO & NM 019990 & $1.68 * *$ \\
\hline D site albumin promoter binding protein & Dbp & NM 016974 & $1.65 *$ \\
\hline lectin, galactose binding, soluble 4 & Lgals4 & NM 010706 & $1.65 * *$ \\
\hline cytochrome P450, family 26 , subfamily b, polypeptide I & Cyp26bl & NM 175475 & $1.62 * *$ \\
\hline 23 I0043NIORik & & $\underline{X M 979471}$ & $1.55 *$ \\
\hline cold inducible RNA binding protein & Cirbp & NM 007705 & $1.49 *$ \\
\hline FBJ osteosarcoma oncogene & Fos & NM 010234 & $1.49 * *$ \\
\hline 2900060BI4Rik & & & $1.49 *$ \\
\hline early growth response I & Egrl & NM 007913 & $1.46 *$ \\
\hline 18I00I5C04Rik & & NM 025459 & $1.45 *$ \\
\hline seminal vesicle secretion I & Svs I & NM 172888 & $1.44 * *$ \\
\hline \multirow[t]{2}{*}{ Iroquois related homeobox 3 (Drosophila) } & Irx3 & NM 008393 & $1.43 * *$ \\
\hline & $\mathrm{BC} 031353$ & NM 153584 & $1.43 *$ \\
\hline folliculin interacting protein I & Fnipl & NM 173753 & $1.42 * *$ \\
\hline myosin, heavy polypeptide 7 , cardiac muscle, beta & Myh7 & NM 080728 & $1.42 * *$ \\
\hline Cbp/p300-interacting transactivator, with Glu/Asp-rich carboxy-terminal domain, 2 & Cited2 & NM 010828 & $\left.1.4\right|^{*}$ \\
\hline 26I0035DI7Rik & & $\underline{X M 990633}$ & $1.41 * *$ \\
\hline a disintegrin-like and metalloprotease (reprolysin type) with thrombospondin type I motif, I & Adamts I & NM 009621 & $1.40 *$ \\
\hline fructose bisphosphatase 2 & Fbp2 & NM 007994 & $1.40 *$ \\
\hline 2300009N04Rik & & & $1.40 *$ \\
\hline
\end{tabular}

*Data obtained with 2 high-iron and 2 control samples.

** Data obtained with 3 high-iron and 3 control samples.

adipose tissue) Angptl4 may bind directly and inactivate LPL, restricting acquisition of free fatty acids to these sites: it is not shed into plasma from these tissues but rather acts in an autocrine/paracrine fashion. On the other hand, in the liver, which has low LPL expression, Angptl4 is shed to plasma and inhibits LPL in other locations, causing a general reduction of triglyceride utilization and acting as an endocrine factor. Interestingly, we showed a 5-fold increase in the level of Angptl4 transcript in the heart of iron-loaded mice, raising the possibility that early induction of Angptl4 expression could contribute to the pathogenesis of cardiomyopathy in $\mathrm{HH}$. The increased expression of Pdk4 and Angptl4 observed in skeletal mus- sitive tissues (liver, skeletal muscle and adipose tissues) and it is involved in insulin's action to suppress Pdk4 and Angptl4 $[36,44]$.

Myosin light polypeptide 4 (Myl4) (encoding the alkali atrial essential light chain (ELCa)) and myosin light polypeptide 7 (Myl7) (encoding the regulatory light chain (RLC-A)) show a 10-fold up-regulation in the cardiac muscle of iron-loaded mice. Both genes belong to the EFhand family of $\mathrm{Ca}^{2+}$ binding proteins and are part of the myosin molecular complex. They appear to be involved in force development during muscle contraction. ELC is important in the interaction between myosin and actin 
Table 4: Genes with down-regulated expression in the heart during iron overload

\begin{tabular}{|c|c|c|c|}
\hline Gene name & Symbol & Accession. & Fold change \\
\hline uncoupling protein I, mitochondrial & Ucpl & NM 009463 & $-4.47 * *$ \\
\hline actin, alpha I, skeletal muscle & Actal & NM 009606 & $-2.79 *$ \\
\hline chemokine (C-X-C motif) ligand 7 & Cxcl7 & NM 023785 & $-2.41 *$ \\
\hline stearoyl-Coenzyme A desaturase I & Scdl & NM 009127 & $-2.40 * *$ \\
\hline heat shock protein IB & Hspalb & NM 010478 & $-2.25 * *$ \\
\hline heat shock protein 105 & Hspl05 & NM 013559 & $-2.25 * *$ \\
\hline tubulin, beta I, 28I0484G07Rik & Tubbl & & $-2.15 *$ \\
\hline Adipsin & Adn & NM 013459 & $-1.92 * *$ \\
\hline carbonic anhydrase 3 & Car3 & NM 007606 & $-1.91 * *$ \\
\hline Dnaj (Hsp40) homolog, subfamily B, member I & Dnajbl & NM 018808 & $-1.90 * *$ \\
\hline ERBB receptor feedback inhibitor I & Errfil & NM 133753 & $-1.81 * *$ \\
\hline $\begin{array}{l}\text { RIKEN full-length enriched library, clone:F830002EI4 product: hypothetical Phenylalanine-rich region } \\
\text { profile containing protein }\end{array}$ & & AK089567 & $-1.69 * *$ \\
\hline fatty acid synthase & Fasn & NM 007988 & $-1.65 * *$ \\
\hline dickkopf homolog 3 (Xenopus laevis) & Dkk3 & NM 015814 & $-1.61 *$ \\
\hline Wnt inhibitory factor I & Wifl & NM 011915 & $-1.60 * *$ \\
\hline glycoprotein 5 (platelet) & Gp5 & NM 008148 & $-1.57 *$ \\
\hline \multirow[t]{2}{*}{ heat shock protein I, alpha } & Hspca & NM 010480 & $-1.53 * *$ \\
\hline & $\mathrm{mt}-\mathrm{Nd} 5$ & & $-1.52 *$ \\
\hline adipocyte, CIQ and collagen domain containing & Acdc & NM 009605 & $-1.50 * *$ \\
\hline 3-hydroxybutyrate dehydrogenase (heart, mitochondrial) & Bdh & NM 175177 & $-1.50 *$ \\
\hline heat shock protein I, beta & Hspcb & NM 008302 & $-1.49 * *$ \\
\hline 4-aminobutyrate aminotransferase & Abat & NM $17296 \mid$ & $-1.49 * *$ \\
\hline DNA-damage-inducible transcript 4 & Ddit4 & NM 029083 & $-1.49 * *$ \\
\hline cyclin-dependent kinase inhibitor IA & Cdknla & NM 007669 & $-1.49 * *$ \\
\hline heat shock protein I & Hspbl & NM 013560 & $-1.48 * *$ \\
\hline potassium voltage-gated channel, shaker-related subfamily, member 5 & Kcna5 & NM 145983 & $-1.46 * *$ \\
\hline CD9 antigen & $\mathrm{Cd} 9$ & NM 007657 & $-1.45 *$ \\
\hline protein phosphatase I, regulatory (inhibitor) subunit 3C & Ppplr3c & NM 016854 & $-1.44 * *$ \\
\hline $\begin{array}{l}\text { RIKEN full-length enriched library, clone: } 2510042 \mathrm{H} 12 \text { product: weakly similar to RAT HEMOGLOBIN } \\
\text { ALPHA CHAIN (FRAGMENT) [Rattus norvegicus] }\end{array}$ & & AKOII092 & $-1.44 *$ \\
\hline immunoglobulin superfamily, member I & lgsf| & NM 183336 & $-1.43 * *$ \\
\hline SRY-box containing gene 18 & Sox 18 & NM_009236 & $-1.42 *$ \\
\hline phosphatidylinositol $(4,5)$ bisphosphate 5 -phosphatase, A & Pib5pa & NM 172439 & $-1.4 \mid *$ \\
\hline transferrin receptor & Tfrc & NM 011638 & $-1.4 \mid * *$ \\
\hline cysteine and histidine-rich domain (CHORD)-containing, zinc-binding protein I & Chordcl & NM 025844 & $-1.40 * *$ \\
\hline eukaryotic translation elongation factor 2 & Eef2 & NM 007907 & $-1.40 * *$ \\
\hline FERM domain containing 5 & Frmd5 & NM_172673 & $-1.40 * *$ \\
\hline inhibitor of DNA binding I & $|d b|$ & NM 010495 & $-1.40 * *$ \\
\hline procollagen-proline, 2-oxoglutarate 4-dioxygenase (proline 4-hydroxylase), alpha I polypeptide & P4hal & NM 011030 & $-1.40 * *$ \\
\hline protein O-fucosyltransferase 2 & Pofut2 & NM 030262 & $-1.40 *$ \\
\hline I5000I50IORik & & NM 024283 & $-1.40 * *$ \\
\hline
\end{tabular}

*Data obtained with 2 high-iron and 2 control samples.

** Data obtained with 3 high-iron and 3 control samples.

[45]. There are two forms of ELC in the cardiac muscle, ELCa and ELCv (encoded by Myl3). ELCa has a higher performance than ELCV and its elevated accumulation in diseased heart is considered a compensatory response in heart failure [46]. Furthermore, transgenic rats overexpressing ELCa in the heart show an improvement in contractile parameters [47]. These observations open the possibility that the induction of cardiac Myl4 and Myl7 expression observed in our experiments is a compensatory response to early damage produced by iron accumulation. Additionally, according to our microarray results, other myosin genes were induced by iron in mouse heart
$(M y h 7)$ and skeletal muscle (Myl2). Actin filaments play an essential role, along with myosin, in muscle contraction. Curiously, in the present work, iron suppressed the expression of skeletal muscle and smooth muscle isoforms of actin (acta1 and acta2) in the heart, as well as the cardiac isoform (actc1) in skeletal muscle.

The present microarray data analysis identified one gene (Stearoyl-coenzyme A desaturase 1, Scd1), which showed marked upregulation (1.75 fold) in the skeletal muscle and downregulation ( -2.40 fold) in the heart after iron overload. This finding was also confirmed by Q-RT-PCR. 

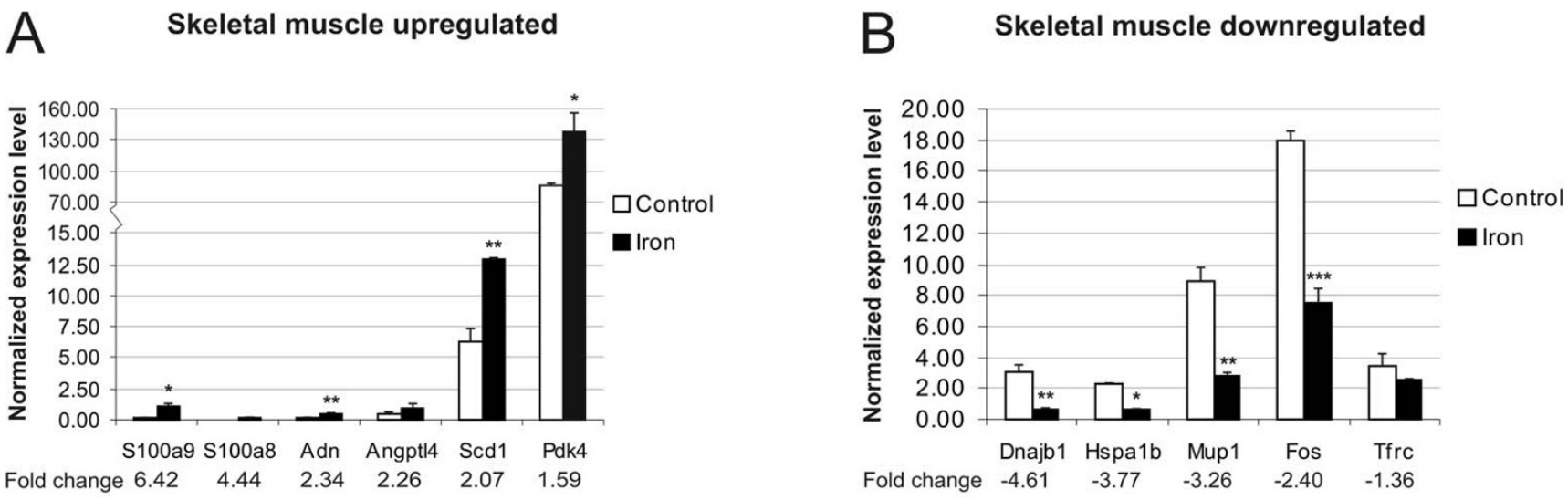

Figure 2

Confirmation of microarray results for skeletal muscle by Q-RT-PCR. The experiments were performed on samples derived from C57BL/6 male mice. The result values are expressed as mean of triplicate runs $+/-$ standard deviation. Statistical significant differences relative to control diet fed mice were determined. $* p<0,05 ; * * p<0,0$ I; ***p $<0,00$ I. A, Q-RT-PCR analysis of 6 genes with up-regulated expression after iron overload. B, Q-RT-PCR evaluation of 5 genes with iron-induced down-regulation of expression by microarray analysis.

Scd1 is an iron-containing enzyme with a central lipogenic role. It catalyzes the insertion of a double bond into fatty acyl-CoA substrates, the preferred one being stearoylCoA, and yielding oleoyl-CoA. Oleic acid is the major monounsaturated fatty acid of membrane phospholipids, triglycerides, cholesterol esters, wax esters and alkyl-1,2diacylglicerol. The (stearic acid/oleic acid) ratio has important effects on cell membrane fluidity and signal transduction. The overexpression of Scd1 has been shown to be associated with genetic predisposition to hepatocarcinogenesis [48]. Scd1 mRNA levels were induced 2.49 times in mouse liver during iron overload (data not shown), an effect that was previously shown in both enteral and parenteral models of iron overload [49]. As Pigeon and coworkers have discussed, most likely the effect of iron on Scd1 expression in the liver is not direct, but a compensatory mechanism in response to the need to renew unsaturated fatty acids.

The FBJ osteosarcoma oncogene (Fos) is a major component of activator-protein-1 (AP-1), a redox-sensitive transcription factor complex, which also includes members of
A

Heart upregulated

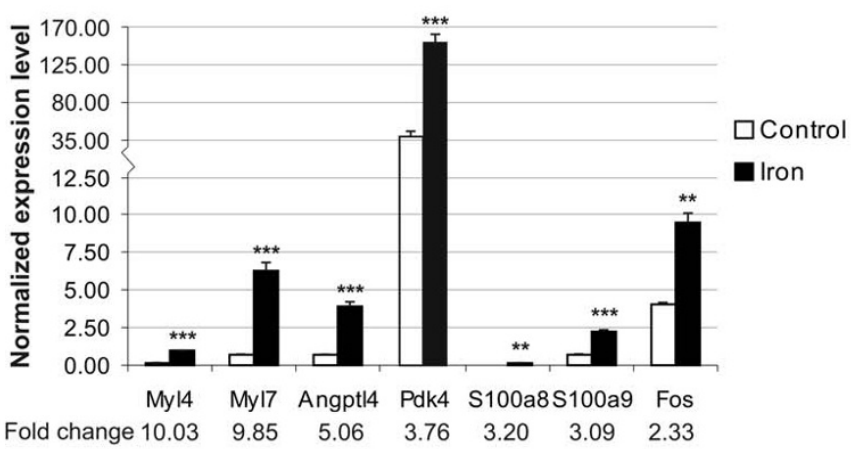

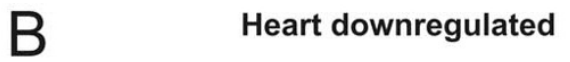

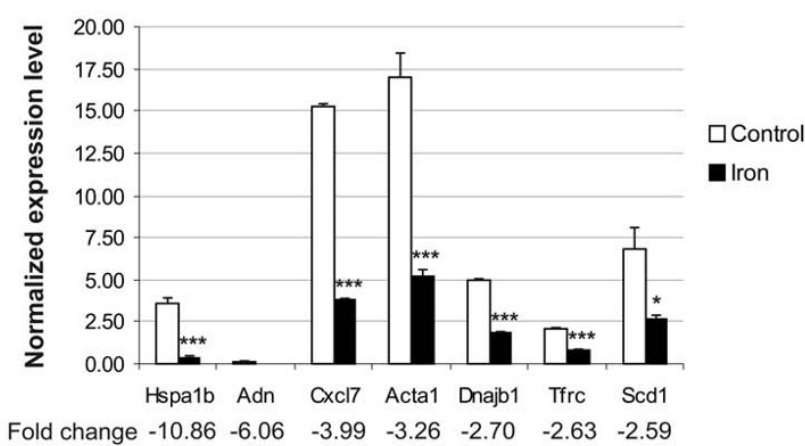

Figure 3

Verification of data obtained for heart samples by microarray analysis using Q-RT-PCR. Samples from C57BL/6 male mice were used in these experiments. The result values are expressed as mean of triplicate runs $+/-$ standard deviation. Statistical significant differences relative to control diet fed mice were determined. $*_{p}<0,05 ; *^{*} p<0,0$ I; *** $p<0,00$ I. A, QRT-PCR evaluation of seven genes with up-regulated expression after iron overload. B, Q-RT-PCR analysis of seven genes with iron-induced down-regulation of expression by microarray. 
A

Angpt14

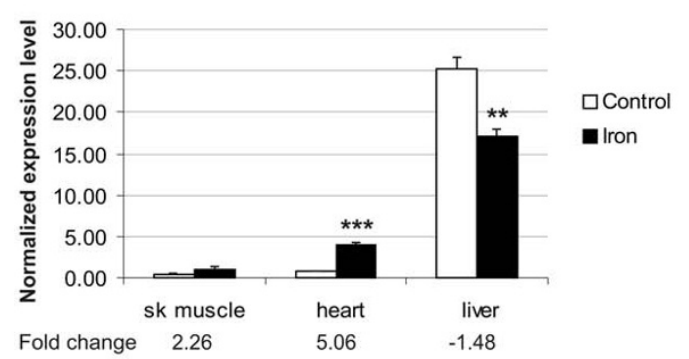

C
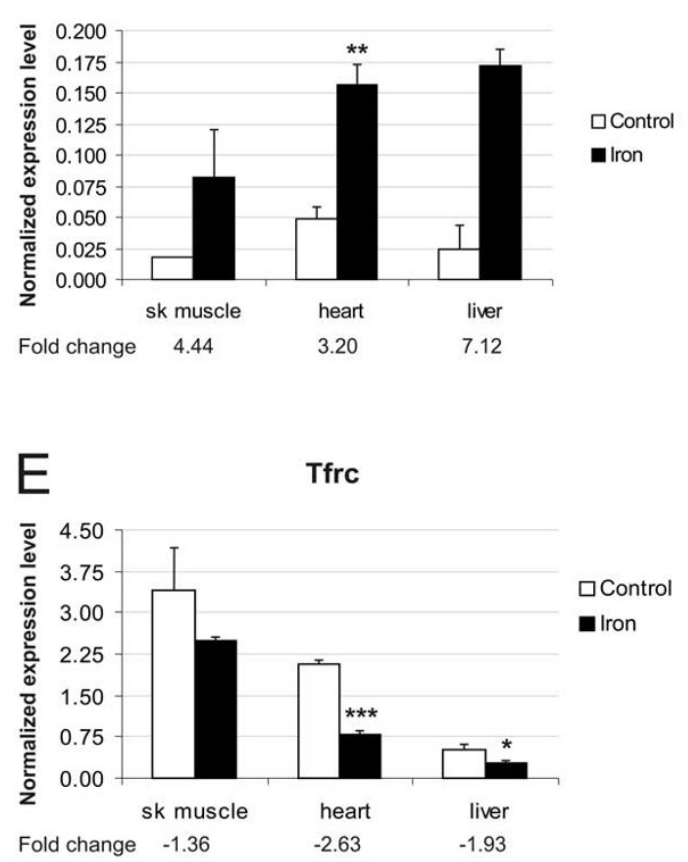

G

Hspa1b

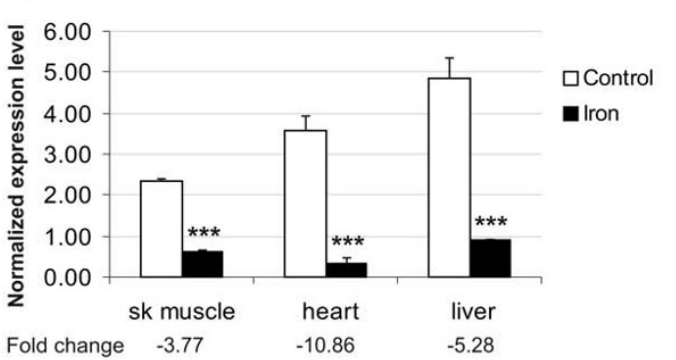

B Pdk4

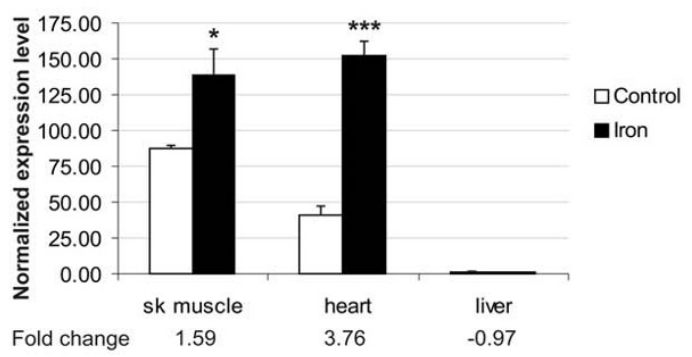

D s100a9

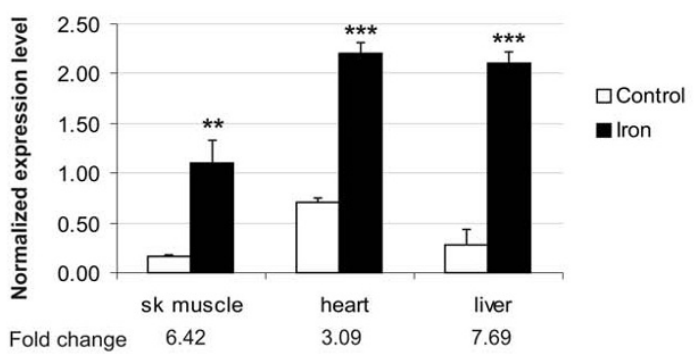

F Dnajb1

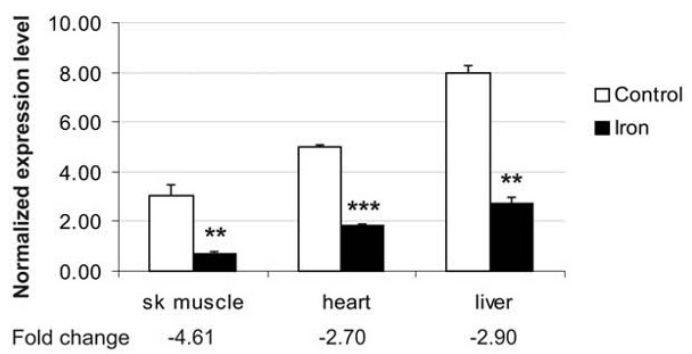

\section{Figure 4}

Expression analysis of genes presenting same trend in muscular tissues and comparison with hepatic expression. C57BL/6 male mice were used in this analysis. The result values are expressed as mean of triplicate runs $+/-$ standard deviation. Statistical significant differences relative to control diet fed mice were determined. $*_{p}<0,05 ; * * p<0,0$ I; $* * * p<$ 0,00 I. A-D, Genes with up-regulated expression in both skeletal muscle and heart after iron overload. E-G, Genes with downregulated expression in skeletal muscle and heart after iron overload. 


\section{Hepcidin1}
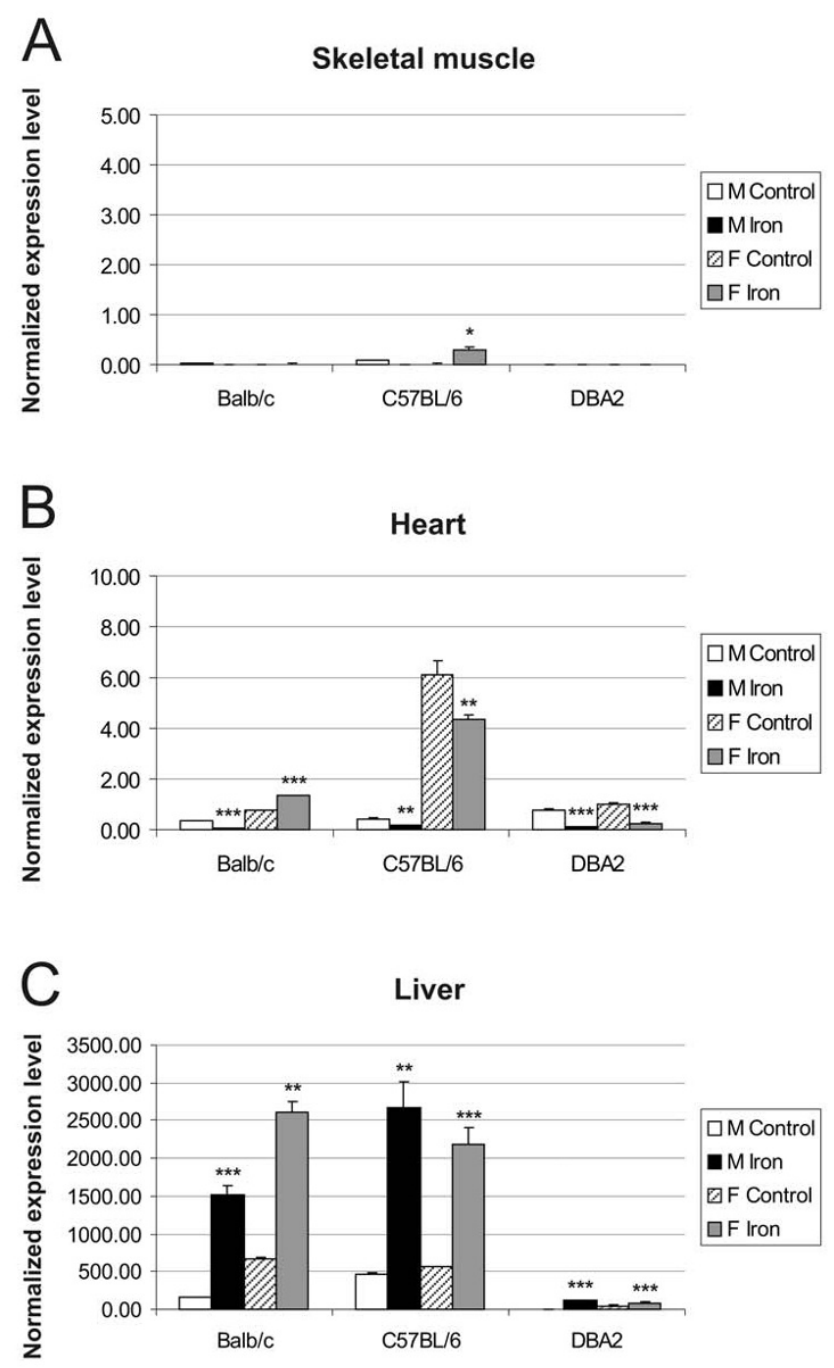

Figure 5

Expression of hepcidin I in skeletal muscle (A), heart (B) and liver (C) assessed by Q-RT-PCR. The expression of hepcidin I transcripts was assessed in control versus iron fed mice of 3 strains (Balb/c, C57BL/6, DBA2). The result values are expressed as mean of triplicate runs $+/$ standard deviation. Statistical significant differences relative to control diet fed mice were determined. ${ }^{*} p<0,05$; $*_{p} p<$ $0,0 \mathrm{I} ; * * *_{p}<0,00 \mathrm{I} . \mathrm{F}=$ female; $\mathrm{M}=$ male.

the Jun (c-Jun, JunB, JunD), Maf and ATF subfamilies. Fos is thought to have an important role in signal transduction, cell proliferation and differentiation. Expression of c-fos and c-jun can be induced by many stimuli and compounds, including some metals such as iron [50]. Accordingly, the present work shows increased expression of cFos in the heart and liver of iron-loaded mice. However, in skeletal muscle, c-Fos was down-regulated and, accord-

\section{Hepcidin2}
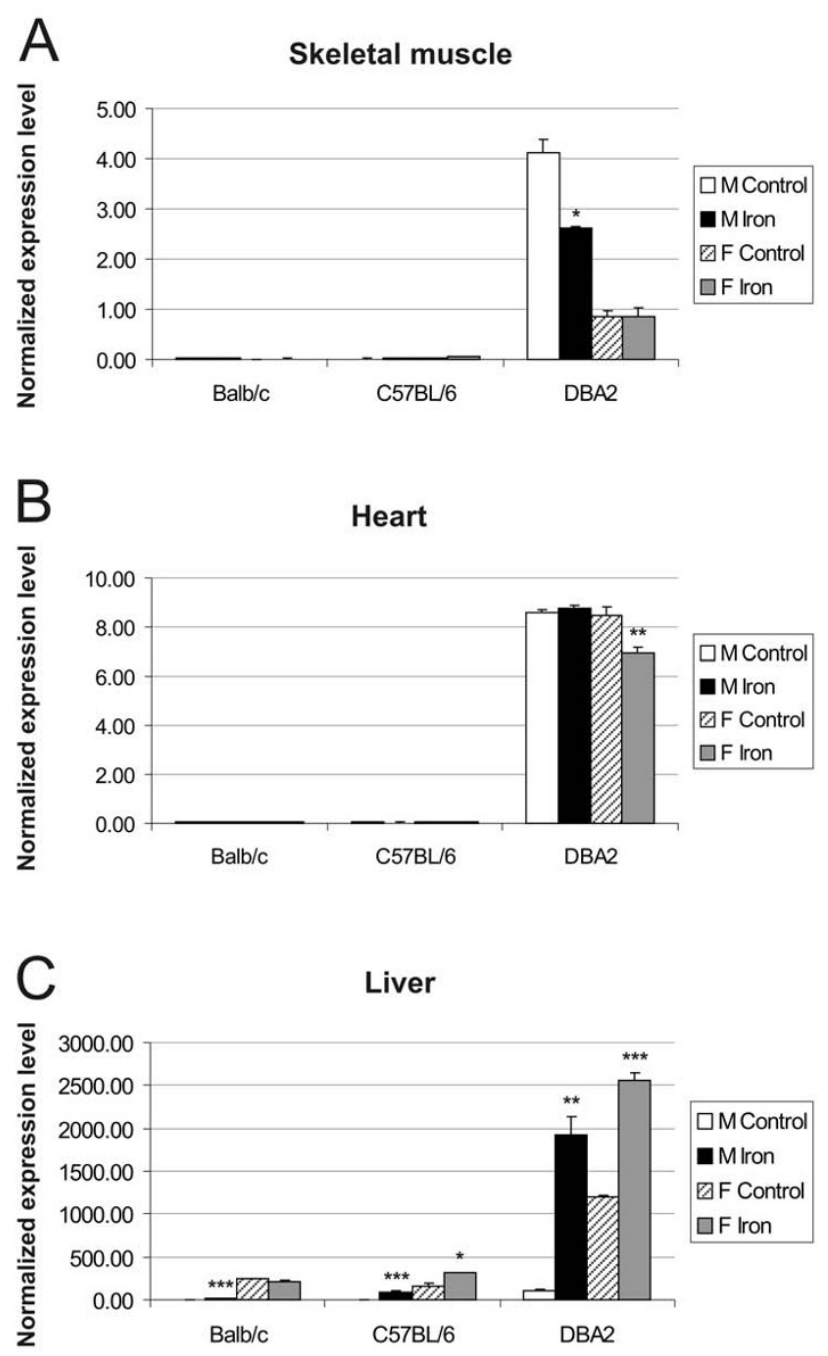

\section{Figure 6}

Q-RT-PCR analysis of hepcidin 2 mRNA expression in skeletal muscle (A), heart (B) and liver (C). The expression of hepcidin2 in control versus iron overloaded mice was analyzed in 3 strains (Balb/c, C57BL/6, DBA2). The result values are expressed as mean of triplicate runs $+/$ standard deviation. Statistical significant differences relative to control diet fed mice were determined. $*_{p}<0,05$; $*^{*} p<$ $0,0 \mathrm{I} ;{ }^{* * *} p<0,00 \mathrm{I} . \mathrm{F}=$ female; $\mathrm{M}=$ male.

ing to the microarray results, the same is true for c-Jun. Probably other mechanisms are influencing the transcription of c-Fos and c-Jun in skeletal muscle. Interestingly, a recent study suggested that c-Jun and JunB negatively regulate the transcription of S100a8 and S100a9 [51]. Furthermore, AP-1 activity had been previously connected to iron metabolism in several ways. For example, AP-1 regulates transcription of ceruloplasmin (the plasma iron oxi- 


\section{HJV}
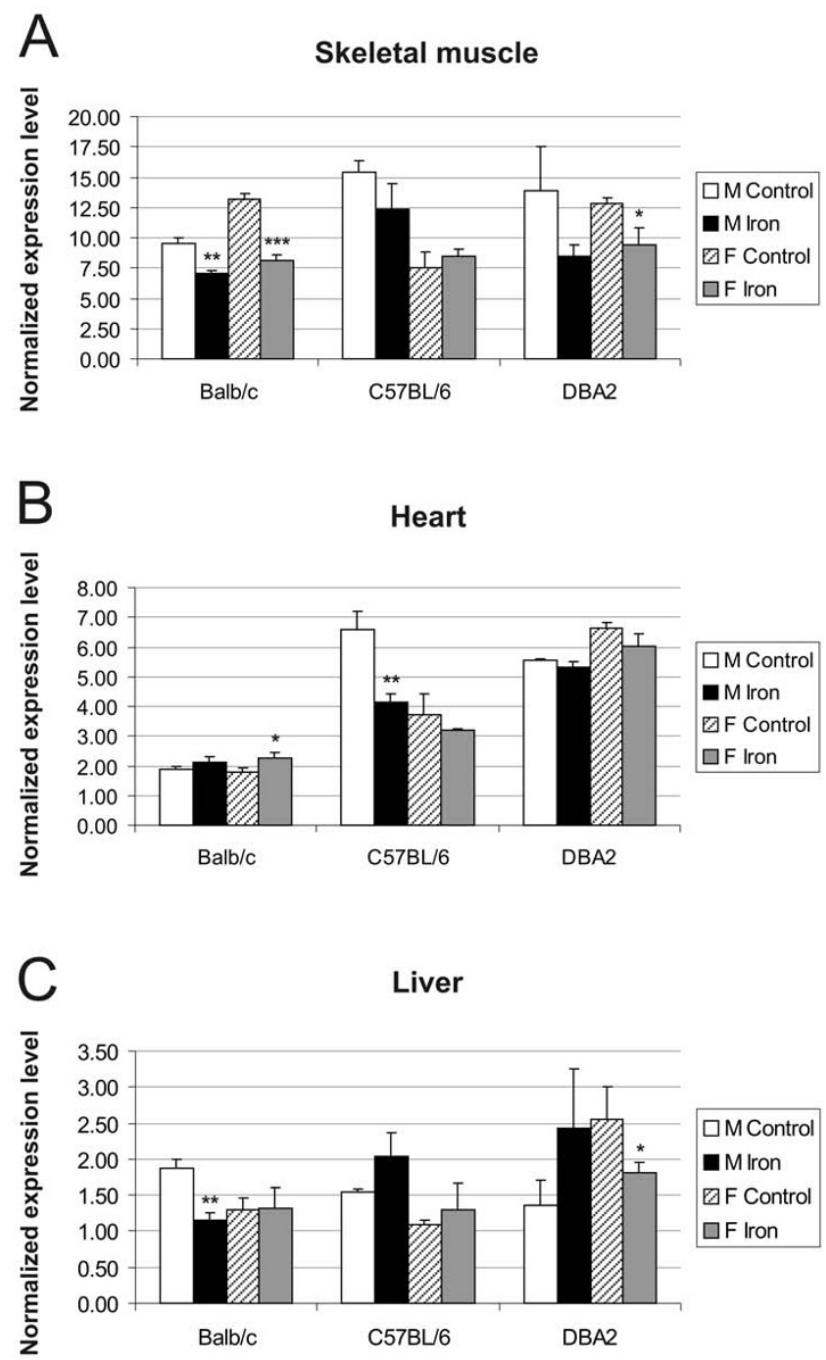

Figure 7

Expression of hemojuvelin (HJV) in skeletal muscle (A), heart (B) and liver (C). Q-RT-PCR analysis of HJV mRNA levels in control versus iron overloaded mice of 3 strains (Balb/c, C57BL/6, DBA2). The result values are expressed as mean of triplicate runs $+/$ - standard deviation. Statistical significant differences relative to control diet fed mice were determined. $* p<0,05 ; * * p<0,0$ I; *** $p<0,00$ I. F $=$ female; $M=$ male.

dase) [52], and the promoter region of HFE contains an AP-1 transcription element [53].

Heat shock proteins, or stress proteins, are expressed in response to heat shock and a variety of other stress stimuli including oxidative free radicals and toxic metal ions. The members of the $70-\mathrm{kDa}$ heat shock protein family (Hsp70) assist cells in maintaining functional proteins

\section{Neogenin}
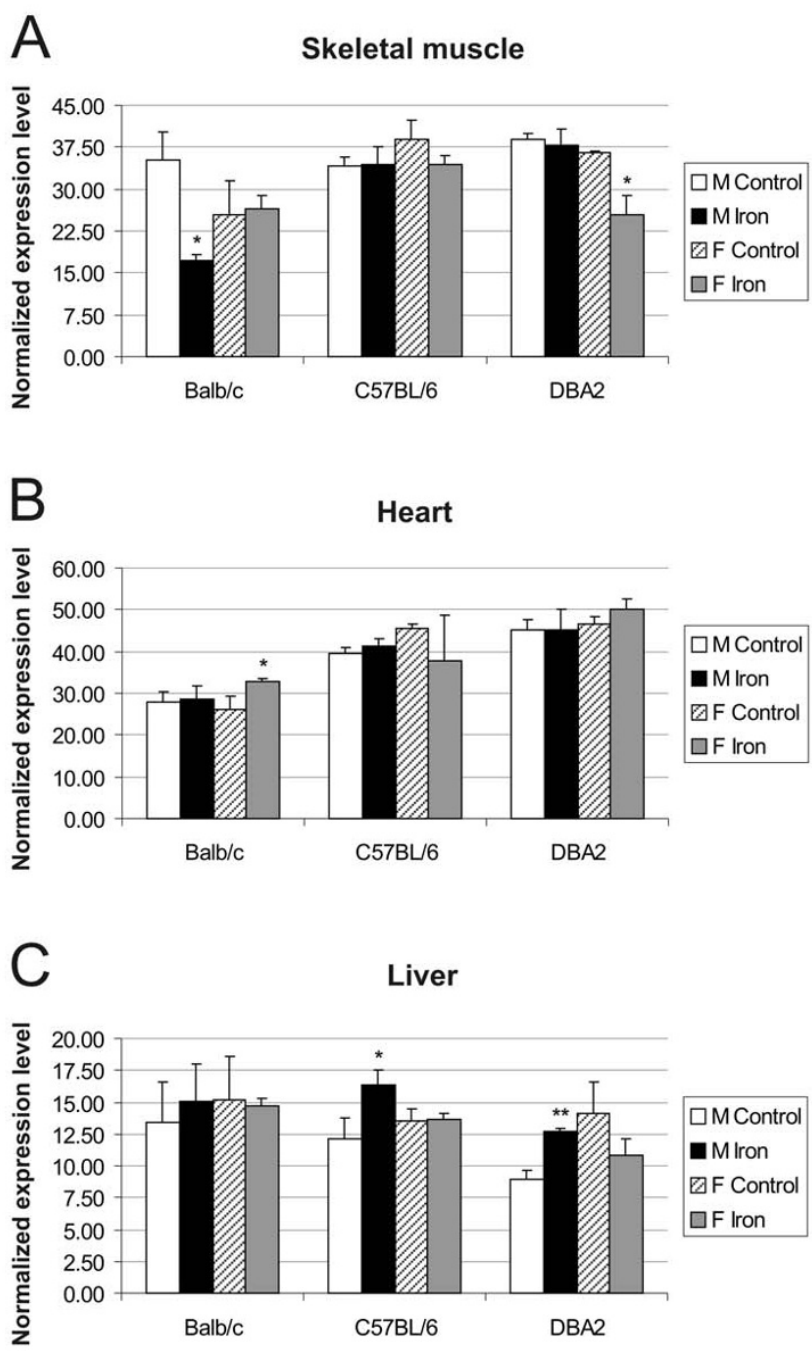

Figure 8

Neogenin transcript levels in skeletal muscle (A), heart (B) and liver (C). 3 mouse strains (Balb/c, C57BL/6, DBA2) were used for this Q-RT-PCR analysis. The result values are expressed as mean of triplicate runs $+/$ - standard deviation. Statistical significant differences relative to control diet fed mice were determined. $*_{p}<0,05$; **p $<0,01$; ***p $<$ $0,00 \mathrm{I} . \mathrm{F}=$ female; $M=$ male.

under stressful conditions [54]. Hsp40 proteins stimulate the ATPase activity of Hsp70 proteins and stabilize the interaction of these chaperons with their substrate proteins [55]. In the present study, dietary iron overload decreased the expression of Hspa1b (a member of Hsp70 family) and Dnajb1 (a member of Hsp40 family) in skeletal muscle, heart and liver of mice as validated by Q-RTPCR. In accordance with these findings, our microarray results also showed decreased expression of several other 
heat shock protein genes in skeletal muscle (Hsp105, Hspca, Hspb1 and Hspa1a) and heart (Hsp105, Hspcb, Hspca and Hspb1) of iron-loaded mice. This unexpected result might represent novel regulatory mechanisms specific to these concrete experimental conditions.

The post-transcriptional regulation of transferrin receptor 1 and divalent metal transporter 1 by iron is mediated through iron-responsive elements located in the 3'untranslated region of their mRNAs [56,57]. As expected, we found decreased Tfrc mRNA expression in skeletal muscle, heart and liver of iron-loaded mice but, surprisingly, the expression of divalent metal transporter 1 was not changed substantially.

The expression levels of hepcidin 1 and hepcidin 2 transcripts in the liver are markedly influenced by strain and gender, in accordance with previous reports [22,23]. DBA2 mice differ markedly in the expression levels of their hepcidin genes when compared with Balb/c and C57BL/6 mice. For DBA2, the difference in hepcidin2 expression was evident not only in liver, but also in the heart and skeletal muscle. These results further demonstrate that iron responses can vary between different mouse strains.

\section{Conclusion}

To conclude, we have identified genes whose expression is altered in skeletal muscle and heart during iron overload. The number of the affected genes and the magnitude of the changes were relatively low, which is probably due to the fact that skeletal muscle and heart are not the primary targets of iron loading. Interestingly, some of the regulated genes identified in this study are involved in modulation of glucose and lipid metabolism, transcription and cellular stress responses. These might represent novel links between iron overload and the pathogenesis of cardiomyopathy and diabetes in $\mathrm{HH}$. Further investigation of these genes may help to understand how iron excess leads to these common $\mathrm{HH}$ manifestations.

\section{Methods}

Animal care and experimental iron overload

The experiments with mice were performed in the laboratory animal centre of the University of Oulu. The mice were kept under specific pathogen-free conditions and the experiments were approved by the Animal Care and Use Committee of the University of Oulu (permission No 102/05). Five male and five female mice from each of three strains (Balb/c, C57BL/6, and DBA/2) were placed on a diet (Lactamin, Stockholm, Sweden) supplemented with 2\% carbonyl iron (Sigma-Aldrich Sweden AB, Stockholm, Sweden, \#C3518) at the age of 10-12 weeks. Equivalent groups of littermates were fed control chow diet without iron supplementation $(0.02 \%$ iron). After 6 weeks of treatment, blood was collected from the mice under anaesthesia. Animals were then sacrificed and liver, skeletal muscle (extensor digitorum longus, EDL) and heart samples were immediately collected and immersed in RNAlater (Ambion, Huntingdon, UK). EDL is relatively easy to identify and isolate and it has been used as a reference muscle in many physiological studies. Liver samples were also collected and stored frozen before measurement of iron content.

\section{Determination of hepatic and cardiac iron content}

Liver and heart tissue samples were analyzed for nonheme iron content using the bathophenanthroline method as described by Torrance and Bothwell [58]. The values are expressed as $\mu \mathrm{g}$ of iron per g dry weight.

\section{RNA isolation}

Total RNA was obtained using RNeasy RNA isolation kit (Qiagen, Valencia, CA) as recommended by the manufacturer. Residual DNA was removed from the samples using RNase-free DNase (Qiagen). RNA concentration and purity were determined using optical density (OD) measurements at 260 and $280 \mathrm{~nm}$. All the samples had an OD260/OD280 ratio of 1.95 or higher.

\section{Microarray analysis}

Microarray studies were performed in the Finnish DNA Microarray Centre at Turku Centre for Biotechnology. Heart and skeletal muscle specimens derived from 3 male C57BL/ 6 mice of each group (iron diet and control diet) were subjected to total RNA extraction. The resulting samples were analyzed individually. $200 \mathrm{ng}$ of total RNA from each sample was amplified using the Illumina ${ }^{\mathrm{TM}}$ RNA TotalPrep Amplification kit (Ambion) following the manufacturer's instructions. The in vitro transcription reaction, which was conducted for $14 \mathrm{~h}$, included labelling of the cRNA by biotinylation.

\section{Hybridization and scanning}

Labelled and amplified material (1.5 $\mu \mathrm{g} /$ array) was hybridized to Illumina's Sentrix Mouse-6 Expression BeadChips $^{\mathrm{TM}}$ (Illumina, Inc., San Diego, CA) (12 samples, 2 chips) at $55^{\circ} \mathrm{C}$ for $18 \mathrm{~h}$ according to Illumina BeadStation $500 \mathrm{X}^{\mathrm{Tм}}$ protocol. Arrays were washed and then stained with $1 \mu \mathrm{g} / \mathrm{ml}$ cyanine3-streptavidin (Amersham Biosciences, Buckinghamshire, UK). The Illumina BeadArray $^{\mathrm{TM}}$ reader was used to scan the arrays according to the manufacturer's instructions. Samples were analyzed using the BeadStudio ${ }^{\mathrm{TM}}$ software from Illumina. The hybridization control report showed problems in 2 of the arrays, corresponding to 2 heart samples, one from a control mouse and the other from an iron-loaded mouse. In both cases, 228 probes failed to hybridize, and therefore, these probes were excluded from the analyses of these 2 samples. 


\section{Data analysis}

Array data were normalized with Inforsense KDE version 2.0.4 (Inforsense, London, UK) using quantile normalization method. The fold-change values were calculated for each gene using the same software. The resulting data were filtered according to a fold-change of 1.4 and -1.4 for upand down-regulated expression, respectively. This value has been proposed as an adequate compromise above which there is a high correlation between microarray and quantitative PCR data, regardless of other factors such as spot intensity and cycle threshold [59].

\section{Quantitative real-time PCR}

The RNA extracts from 5 mice within each study group were equally pooled and RNA samples ( $3 \mu \mathrm{g}$ from liver and $1.5 \mu \mathrm{g}$ from heart and skeletal muscle) were converted into first strand cDNA with a First Strand cDNA Synthesis kit (Fermentas, Burlington, Canada) using random hexamer primers according to the protocol recommended by the manufacturer. The relative expression levels of target genes in mouse liver, skeletal muscle and heart were assessed by quantitative real-time RT-PCR using the Lightcycler detection system (Roche, Rotkreuz, Switzerland). The validations of microarray data were performed on samples obtained from C57BL/6 mice, while mRNA expression of hepcidin1, hepcidin2, hemojuvelin and neogenin was studied in three strains (Balb/c, C57BL/6, and DBA/2). Four housekeeping genes (Actb ( $\beta$-actin), Gapdh (glyceraldehyde-3-phosphate dehydrogenase), Hprt1 (hypoxanthine phosphoribosyl-transferase I), and Sdha (succinate dehydrogenase complex subunit A)) were used as internal controls to normalize the cDNA samples for potential quality and quantity differences. The primers for the housekeeping genes and for mouse $\mathrm{Hjv}$ and Neo target genes have been described earlier [19]. Mouse Hamp1 and Hamp2 primers have been also previously characterized [60]. The primer sets for the remaining target genes in this study are shown in Table 5. Most of them were designed using Primer3 [61], based on the complete cDNA sequences deposited in GenBank. The specificity of the primers was verified using NCBI Basic Local Alignment and Search Tool (Blast) [62]. When possible, and in order to avoid amplification of contaminating genomic DNA, both primers from each set were specific to different exons.

Each PCR reaction was performed in a total volume of 20 $\mu \mathrm{l}$ containing $0.5 \mu \mathrm{l}$ of first strand cDNA, $1 \times$ of QuantiTect SYBR Green PCR Master Mix (Qiagen, Hilden, Germany), and $0.5 \mu \mathrm{M}$ of each primer. Amplification and detection were carried out as follows: After an initial 15-min activation step at $95^{\circ} \mathrm{C}$, amplification was performed in a 3-step cycling procedure: denaturation at $95^{\circ} \mathrm{C}, 15 \mathrm{~s}$, ramp rate $20^{\circ} \mathrm{C} / \mathrm{s}$; annealing temperature determined according to the melting temperature for each primer pair, $20 \mathrm{~s}$, ramp rate $20^{\circ} \mathrm{C} / \mathrm{s}$; and elongation at $72^{\circ} \mathrm{C}, 15 \mathrm{~s}$, ramp rate $20^{\circ} \mathrm{C} / \mathrm{s}$ for 45 cycles and final cooling step. Melting curve analysis was always performed after the amplification to check PCR specificity. To quantify the levels of transcripts in the studied tissues, a standard curve was established for each gene using 5-fold serial dilutions of known concentrations of purified PCR products generated from the same primer sets. Every cDNA sample was tested in triplicate and the obtained crossing point $(\mathrm{Cp})$ value facilitated the determination of the levels of starting message using a specific standard curve. The geometric mean of the 4 internal control genes was used as an accurate normalization factor for gene expression levels [63]. The normalization factor is always considered as a value of 100 and the final result is expressed as relative mRNA expression level.

\section{Statistical analyses}

The mean values and standard deviations were calculated from the individuals in each group for the iron measurements and from technical triplicates for the Q-RT-PCR experiments. The Student's $t$-test (unpaired, 2-tailed) was used to analyze statistically the differences in iron content and in gene expression between control and iron loaded mice. Theoretically, the Q-PCR technology used herein can detect a minimum of 100 copies of starting material. In order to avoid wrong use of the statistical methods, these were not applied to data with raw values below 300 copies.

\section{List of Abbreviations}

BMP- bone morphogenetic protein;

ELC- essential light chain;

HH- hereditary hemochromatosis;

LPL- lipoprotein lipase;

OD- optical density;

Q-RT-PCR - quantitative reverse-transcription PCR;

RGM- repulsive guidance molecule;

RLC- regulatory light chain.

\section{Authors' contributions}

AR participated in sample collection and preparation, designed primers, carried out the Q-RT-PCR and drafted the manuscript. MH performed microarray data analysis. LK carried out microarray data analysis. REF, RSB and BRB provided materials, participated in experimental design and made critical reviewing of the manuscript. SP conceived the study, participated in its design and coordination, participated in sample collection and made critical reviewing of the manuscript. All authors read and approved the final manuscript. 
Table 5: Sequences of the primers used in this study

\begin{tabular}{|c|c|c|c|c|c|}
\hline Symbol & Name & $\begin{array}{c}\text { GenBank } \\
\text { Accession No. }\end{array}$ & Forward primer (5'-3') & Reverse primer (5'-3') & Source \\
\hline Angpt/4 & Angiopoietin - like 4 & NM 020581 & CACGCACCTAGACAATGGA & AGAGGCTGGATCTGGAAA & * \\
\hline$P d k 4$ & Pyruvate dehydrogenase kinase, isoenzyme 4 & NM 013743 & GATTGACATCCTGCCTGACC & TCTGGTCTTCTGGGCTCTTC & * \\
\hline $5100 a 8$ & Calgranulin A, S100 calcium binding protein A8 & NM 013650 & GGAAATCACCATGCCCTCTAC & GCCACACCCACTTTTATCACC & * \\
\hline $5100 a 9$ & Calgranulin B, S100 calcium binding protein A9 & NM 009114 & CGACACCTTCCATCAATACTC & GAGGGCTTCATTTCTCTTCTC & * \\
\hline Fos & FBJ osteosarcoma oncogene & NM 010234 & CGGGTTTCAACGCCGACTA & TTGGCACTAGAGACGGACAGA & RTprimerDB, 3328 \\
\hline Myl4 & Myosin light polypeptide 4 & NM 010858 & GGGTAAAGCACGTTTCTCCA & AGGGAAGGTTGTGGGTCAG & * \\
\hline Myl7 & Myosin light polypeptide 7 & NM 022879 & TCACCGTCTTCCTCACACTC & GCTGCTTGAACTCTTCCTTG & * \\
\hline Actal & Actin alpha I & NM 009606 & CCAAAGCTAACCGGGAGAA & CCCCAGAATCCAACACGA & * \\
\hline Cxcl7 & Chemokine (C-X-C motif) ligand 7 & NM 023785 & GCCCACTTCATAACCTCCA & ATCACTTCCACATCAGCACA & * \\
\hline Tfrc & Transferrin receptor I & NM 011638 & TCATGAGGGAAATCAATGATCGTA & GCCCCAGAAGATATGTCGGAA & QPPD, 1607 \\
\hline Scdl & Stearoyl-Coenzyme A desaturase I & NM 009127 & TGGGTTGGCTGCTTGTG & GCGTGGGCAGGATGAAG & QPPD, 1847 \\
\hline Adn & Adipsin, complement factor $D$ & NM 013459 & AACCGGACAACCTGCAATC & CCCACGTAACCACACCTTC & * \\
\hline Mup I & Major urinary protein I & NM 031188 & CTCTATGGCCGAGAACCAGA & AGCGATTGGCATTGGATAGG & * \\
\hline Dnajb I & Dnal (Hsp40) homolog, subfamily B, member I & NM 018808 & CGACCGCTATGGAGAGGAA & GCCACCGAAGAACTCAGCA & * \\
\hline Hspalb & Heat shock protein IB & NM 010478 & GAGGAGTTCAAGAGGAAGCA & GCGTGATGGATGTGTAGAAG & * \\
\hline
\end{tabular}

* designed using Primer3 http://puma.fmvz.usp.br/primer3/primer3 www.cgi 


\section{Acknowledgements}

We thank Dr. Jokke Hannuksela and Dr. Mari Leppilampi for their help with tissue sample collection, and Rosemary O'Neill for iron measurements. We are grateful to the staff of the Finnish microarray core facility at Turku Centre of Biotechnology, especially Päivi Junni, for skilful technical assistance. This work was supported by grants from the Academy of Finland, Finnish Cultural Foundation, Emil Aaltonen Foundation, U.S. Public Health Services (NIH grants DK4I816 and HL66225), and Sigrid Juselius Foundation.

\section{References}

I. Fleming RE, Bacon BR: Orchestration of iron homeostasis. $N$ Engl J Med 2005, 352(I7): I74|- 1744.

2. Camaschella C, Roetto A, Cali A, De Gobbi M, Garozzo G, Carella M, Majorano N, Totaro A, Gasparini P: The gene TFR2 is mutated in a new type of haemochromatosis mapping to 7q22. Nat Genet 2000, 25(I): $14-15$

3. Feder JN, Gnirke A, Thomas W, Tsuchihashi Z, Ruddy DA, Basava A Dormishian F, Domingo R Jr., Ellis MC, Fullan A, Hinton LM, Jones NL, Kimmel BE, Kronmal GS, Lauer P, Lee VK, Loeb DB, Mapa FA, McClelland E, Meyer NC, Mintier GA, Moeller N, Moore T, Morikang E, Prass CE, Quintana L, Starnes SM, Schatzman RC, Brunke KJ, Drayna DT, Risch NJ, Bacon BR, Wolff RK: A novel MHC class l-like gene is mutated in patients with hereditary haemochromatosis. Nat Genet 1996, 13(4):399-408.

4. Papanikolaou G, Samuels ME, Ludwig EH, MacDonald ML, Franchini PL, Dube MP, Andres L, MacFarlane J, Sakellaropoulos N, Politou M, Nemeth E, Thompson J, Risler JK, Zaborowska C, Babakaiff R, Radomski CC, Pape TD, Davidas O, Christakis J, Brissot P, Lockitch G, Ganz T, Hayden MR, Goldberg YP: Mutations in HFE2 cause iron overload in chromosome Iq-linked juvenile hemochromatosis. Nat Genet 2004, 36(I):77-82.

5. Roetto A, Papanikolaou G, Politou M, Alberti F, Girelli D, Christakis J Loukopoulos D, Camaschella C: Mutant antimicrobial peptide hepcidin is associated with severe juvenile hemochromatosis. Nat Genet 2003, 33(I):2I-22.

6. Montosi G, Donovan A, Totaro A, Garuti C, Pignatti E, Cassanelli S, Trenor CC, Gasparini P, Andrews NC, Pietrangelo A: Autosomaldominant hemochromatosis is associated with a mutation in the ferroportin (SLCIIA3) gene. J Clin Invest 200I, 108(4):619-623.

7. Niajou OT, Vaessen N, Joosse M, Berghuis B, van Dongen JW, Breuning MH, Snijders PJ, Rutten WP, Sandkuijl LA, Oostra BA, van Duijn CM, Heutink P: A mutation in SLCIIA3 is associated with autosomal dominant hemochromatosis. Nat Genet 200I, 28(3):2|3-2|4.

8. Bridle KR, Frazer DM, Wilkins SJ, Dixon JL, Purdie DM, Crawford DH, Subramaniam VN, Powell LW, Anderson GJ, Ramm GA: Disrupted hepcidin regulation in HFE-associated haemochromatosis and the liver as a regulator of body iron homoeostasis. Lancet 2003, 36 I (9358):669-673.

9. Nemeth E, Roetto A, Garozzo G, Ganz T, Camaschella C: Hepcidin is decreased in TFR2 hemochromatosis. Blood 2005, 105(4): $1803-1806$.

10. Nemeth E, Tuttle MS, Powelson J, Vaughn MB, Donovan A, Ward DM, Ganz T, Kaplan J: Hepcidin regulates cellular iron efflux by binding to ferroportin and inducing its internalization. Science 2004, 306(5704):2090-2093.

II. Abboud S, Haile DJ: A novel mammalian iron-regulated protein involved in intracellular iron metabolism. J Biol Chem 2000, 275(26): 19906-19912.

12. Zhang AS, West AP Jr., Wyman AE, Bjorkman PJ, Enns CA: Interaction of hemojuvelin with neogenin results in iron accumulation in human embryonic kidney $\mathbf{2 9 3}$ cells. J Biol Chem 2005 280(40):33885-33894.

13. Kuninger D, Kuns-Hashimoto R, Kuzmickas R, Rotwein P: Complex biosynthesis of the muscle-enriched iron regulator RGMc. J Cell Sci 2006, I I 9(Pt 16):3273-3283

14. Lin L, Goldberg YP, Ganz T: Competitive regulation of hepcidin mRNA by soluble and cell-associated hemojuvelin. Blood 2005, 106(8):2884-2889.

15. Silvestri L, Pagani A, Fazi C, Gerardi G, Levi S, Arosio P, Camaschella C: Defective targeting of hemojuvelin to plasma membrane is a common pathogenetic mechanism in juvenile hemochromatosis. Blood 2007, 109( I 0):4503-45I0.
16. Babitt JL, Huang FW, Wrighting DM, Xia Y, Sidis Y, Samad TA, Campagna JA, Chung RT, Schneyer AL, Woolf CJ, Andrews NC, Lin HY: Bone morphogenetic protein signaling by hemojuvelin regulates hepcidin expression. Nat Genet 2006, 38(5):53I-539.

17. Babitt JL, Huang FW, Xia Y, Sidis Y, Andrews NC, Lin HY: Modulation of bone morphogenetic protein signaling in vivo regulates systemic iron balance. J Clin Invest 2007, I I 7(7): 1933-1939.

18. Zhang AS, Anderson SA, Meyers KR, Hernandez C, Eisenstein RS, Enns CA: Evidence that inhibition of hemojuvelin shedding in response to iron is mediated through neogenin. J Biol Chem 2007, 282(17): | 2547-12556

19. Rodriguez A, Pan P, Parkkila S: Expression studies of neogenin and its ligand hemojuvelin in mouse tissues. J Histochem Cytochem 2007, 55(I):85-96.

20. Niederau C, Fischer R, Purschel A, Stremmel W, Haussinger D, Strohmeyer G: Long-term survival in patients with hereditary hemochromatosis. Gastroenterology 1996, I I0(4): I I07-I I I 9.

21. DeNardo DG, Kim HT, Hilsenbeck S, Cuba V, Tsimelzon A, Brown $\mathrm{PH}$ : Global gene expression analysis of estrogen receptor transcription factor cross talk in breast cancer: identification of estrogen-induced/activator protein-I-dependent genes. Mol Endocrinol 2005, 19(2):362-378.

22. Courselaud B, Troadec MB, Fruchon S, llyin G, Borot N, Leroyer P, Coppin H, Brissot P, Roth MP, Loreal O: Strain and gender modulate hepatic hepcidin I and 2 mRNA expression in mice. Blood Cells Mol Dis 2004, 32(2):283-289.

23. Krijt J, Cmejla R, Sykora V, Vokurka M, Vyoral D, Necas E: Different expression pattern of hepcidin genes in the liver and pancreas of C57BL/6N and DBA/2N mice. J Hepatol 2004, 40(6):89I-896

24. Krijt ], Vokurka M, Chang KT, Necas E: Expression of Rgmc, the murine ortholog of hemojuvelin gene, is modulated by development and inflammation, but not by iron status or erythropoietin. Blood 2004, 104(13):4308-4310.

25. Bondi A, Valentino P, Daraio F, Porporato P, Gramaglia E, Carturan $S$, Gottardi E, Camaschella C, Roetto A: Hepatic expression of hemochromatosis genes in two mouse strains after phlebotomy and iron overload. Haematologica 2005, 90(9): I I6I-I I67.

26. Britton RS: Metal-induced hepatotoxicity. Semin Liver Dis 1996, 16(1):3-12.

27. Johne B, Fagerhol MK, Lyberg T, Prydz H, Brandtzaeg P, NaessAndresen CF, Dale I: Functional and clinical aspects of the myelomonocyte protein calprotectin. Mol Pathol 1997, 50(3): II $13-123$.

28. Gebhardt C, Nemeth J. Angel P, Hess J: SI00A8 and SI00A9 in inflammation and cancer. Biochem Pharmacol 2006, 72(II):|622-|63|.

29. Carlsson H, Yhr M, Petersson S, Collins N, Polyak K, Enerback C Psoriasin (SIO0A7) and calgranulin-B (SIO0A9) induction is dependent on reactive oxygen species and is downregulated by Bcl-2 and antioxidants. Cancer Biol Ther 2005, 4(9):998-1005.

30. Grimbaldeston MA, Geczy CL, Tedla N, Finlay-Jones Jj, Hart PH: SI00A8 induction in keratinocytes by ultraviolet A irradiation is dependent on reactive oxygen intermediates. J Invest Dermatol 2003, I 2 I(5): I 168-1174.

31. Sen CK, Packer L: Antioxidant and redox regulation of gene transcription. Faseb J 1996, 10(7):709-720.

32. Fuller SJ, Randle PJ: Reversible phosphorylation of pyruvate dehydrogenase in rat skeletal-muscle mitochondria. Effects of starvation and diabetes. Biochem J 1984, 21 9(2):635-646.

33. Feldhoff PW, Arnold J, Oesterling B, Vary TC: Insulin-induced activation of pyruvate dehydrogenase complex in skeletal muscle of diabetic rats. Metabolism 1993, 42(5):6I5-623.

34. Wu P, Sato J, Zhao Y, Jaskiewicz J, Popov KM, Harris RA: Starvation and diabetes increase the amount of pyruvate dehydrogenase kinase isoenzyme 4 in rat heart. Biochem J 1998, 329 ( Pt I): $|97-20|$.

35. Lee FN, Zhang L, Zheng D, Choi WS, Youn JH: Insulin suppresses PDK-4 expression in skeletal muscle independently of plasma FFA. Am J Physiol Endocrinol Metab 2004, 287(I):E69-74.

36. $\mathrm{Kim}$ YI, Lee FN, Choi WS, Lee S, Youn JH: Insulin regulation of skeletal muscle PDK4 mRNA expression is impaired in acute insulin-resistant states. Diabetes 2006, 55(8):23 II-23। 7 .

37. Peters SJ, Harris RA, Wu P, Pehleman TL, Heigenhauser GJ, Spriet LL: Human skeletal muscle PDH kinase activity and isoform 
expression during a 3-day high-fat/low-carbohydrate diet. Am J Physiol Endocrinol Metab 200 I, 28 I (6): EI I II-8.

38. Kraegen EW, Clark PW, Jenkins AB, Daley EA, Chisholm DJ, Storlien $\mathrm{LH}$ : Development of muscle insulin resistance after liver insulin resistance in high-fat-fed rats. Diabetes 1991, 40(II): I397-I 403.

39. Kim JK, Wi JK, Youn JH: Metabolic impairment precedes insulin resistance in skeletal muscle during high-fat feeding in rats. Diabetes 1996, 45(5):65I-658

40. Bacon BR: Hemochromatosis: diagnosis and management. Gastroenterology 200I, I 20(3):718-725.

4I. Yu X, Burgess SC, Ge H, Wong KK, Nassem RH, Garry DJ, Sherry $A D$, Malloy CR, Berger JP, Li C: Inhibition of cardiac lipoprotein utilization by transgenic overexpression of Angptl4 in the heart. Proc Natl Acad Sci U S A 2005, 102(5): I767-1772.

42. Koster A, Chao YB, Mosior M, Ford A, Gonzalez-DeWhitt PA, Hale JE, Li D, Qiu Y, Fraser CC, Yang DD, Heuer JG, Jaskunas SR, Eacho P. Transgenic angiopoietin-like (angptl)4 overexpression and targeted disruption of angptl4 and angpt/3: regulation of triglyceride metabolism. Endocrinology 2005, I 46( I I):4943-4950.

43. $\mathrm{Li} \mathrm{C}$ : Genetics and regulation of angiopoietin-like proteins 3 and 4. Curr Opin Lipidol 2006, I7(2): I52-156.

44. Yamada T, Ozaki N, Kato Y, Miura Y, Oiso Y: Insulin downregulates angiopoietin-like protein 4 mRNA in 3T3-LI adipocytes. Biochem Biophys Res Commun 2006, 347(4): I I38-I I 44.

45. VanBuren P, Waller GS, Harris DE, Trybus KM, Warshaw DM, Lowey $S$ : The essential light chain is required for full force production by skeletal muscle myosin. Proc Natl Acad Sci U S A 1994 9I(26): I2403-I2407.

46. Abdelaziz AI, Pagel I, Schlegel WP, Kott M, Monti J, Haase H, Morano I: Human atrial myosin light chain I expression attenuates heart failure. Adv Exp Med Biol 2005, 565:283-92; discussion 92, 405-I5.

47. Abdelaziz Al, Segaric J, Bartsch H, Petzhold D, Schlegel WP, Kott M, Seefeldt I, Klose J, Bader M, Haase H, Morano I: Functional characterization of the human atrial essential myosin light chain (hALC-I) in a transgenic rat model. J Mol Med 2004, 82(4):265-274.

48. Falvella FS, Pascale RM, Gariboldi M, Manenti G, De Miglio MR, Simile MM, Dragani TA, Feo F: Stearoyl-CoA desaturase I (Scd I) gene overexpression is associated with genetic predisposition to hepatocarcinogenesis in mice and rats. Carcinogenesis 2002, 23(II): 1933-1936.

49. Pigeon C, Legrand $\mathrm{P}$, Leroyer $\mathrm{P}$, Bouriel $\mathrm{M}$, Turlin B, Brissot $\mathrm{P}$, Loreal $O$ : Stearoyl coenzyme $A$ desaturase I expression and activity are increased in the liver during iron overload. Biochim Biophys Acta 200I, I535(3):275-284.

50. Maki A, Berezesky IK, Fargnoli J, Holbrook NJ, Trump BF: Role of $[\mathrm{Ca2}+] \mathrm{i}$ in induction of c-fos, c-jun, and c-myc mRNA in rat PTE after oxidative stress. Faseb J 1992, 6(3):919-924.

5I. Zenz R, Eferl R, Kenner L, Florin L, Hummerich L, Mehic D, Scheuch $\mathrm{H}$, Angel P, Tschachler E, Wagner EF: Psoriasis-like skin disease and arthritis caused by inducible epidermal deletion of Jun proteins. Nature 2005, 437(7057):369-375.

52. Das D, Tapryal N, Goswami SK, Fox PL, Mukhopadhyay CK: Regulation of ceruloplasmin in human hepatic cells by redox active copper: identification of a novel AP-I site in the ceruloplasmin gene. Biochem J 2007, 402(I): |35- I 4I.

53. Sanchez M, Queralt R, Bruguera M, Rodes J, Oliva R: Cloning, sequencing and characterization of the rat hereditary hemochromatosis promoter: comparison of the human, mouse and rat HFE promoter regions. Gene 1998, 225(I-2):77-87.

54. Mayer MP, Bukau B: Hsp70 chaperones: cellular functions and molecular mechanism. Cell Mol Life Sci 2005, 62(6):670-684

55. Fan CY, Lee S, Cyr DM: Mechanisms for regulation of Hsp70 function by Hsp40. Cell Stress Chaperones 2003, 8(4):309-316.

56. Casey JL, Hentze MW, Koeller DM, Caughman SW, Rouault TA Klausner RD, Harford JB: Iron-responsive elements: regulatory RNA sequences that control mRNA levels and translation. Science 1988, 240(4854):924-928.

57. Cairo G, Pietrangelo A: Iron regulatory proteins in pathobiology. Biochem J 2000, 352 Pt 2:24I-250.

58. Torrance JD, Bothwell TH: A simple technique for measuring storage iron concentrations in formalinised liver samples. Afr J Med Sci 1968, 33:9-II.
59. Morey JS, Ryan JC, Van Dolah FM: Microarray validation: factors influencing correlation between oligonucleotide microarrays and real-time PCR. Biol Proced Online 2006, 8:175-193.

60. Ilyin G, Courselaud B, Troadec MB, Pigeon C, Alizadeh M, Leroyer P, Brissot $\mathrm{P}$, Loreal $\mathrm{O}$ : Comparative analysis of mouse hepcidin I and 2 genes: evidence for different patterns of expression and co-inducibility during iron overload. FEBS Lett 2003, 542(13):22-26.

61. Primer3 [http://puma.fmvz.usp.br/primer3/primer3 www.cgi]

62. BLAST: Basic Local Alignment and Search Tool [http:// www.ncbi.nlm.nih.gov/BLAST/]

63. Vandesompele J, De Preter K, Pattyn F, Poppe B, Van Roy N, De Paepe A, Speleman F: Accurate normalization of real-time quantitative RT-PCR data by geometric averaging of multiple internal control genes. Genome Biol 2002, 3(7):RESEARCH0034.
Publish with BioMed Central and every scientist can read your work free of charge

"BioMed Central will be the most significant development for disseminating the results of biomedical research in our lifetime. "

Sir Paul Nurse, Cancer Research UK

Your research papers will be:

- available free of charge to the entire biomedical community

- peer reviewed and published immediately upon acceptance

- cited in PubMed and archived on PubMed Central

- yours - you keep the copyright
BioMedcentral 